\title{
Comparison and analysis of Wuding and avian chicken skeletal muscle satellite cells
}

\author{
H.Q. Tong ${ }^{1 *}$, Z.Q. Jiang ${ }^{1 *}$, T.F. Dou ${ }^{1}$, Q.H. Li ${ }^{1}$, Z.Q. Xu ${ }^{2}$, L.X. Liu ${ }^{1}$, \\ D.H. Gu' ${ }^{2}$ H. Rong', Y. Huang 1 , X.B. Chen ${ }^{1}$, M. Jois ${ }^{3}$, M.F.W. te Pas ${ }^{4}$, \\ C.R. Ge ${ }^{1}$ and J.J. Jia ${ }^{1}$
}

${ }^{1}$ Yunnan Provincial Key Laboratory of Animal Nutrition and Feed, Yunnan Agricultural University, Kunming, Yunnan Province, China ${ }^{2}$ Department of Food Science, Yunnan Agricultural University, Kunming, Yunnan Province, China ${ }^{3}$ School of Life Sciences Faculty of Science, Technology and Engineering La Trobe University, Bundoora, Victoria, Australia ${ }^{4}$ Animal Breeding and Genetics Centre, Wageningen UR Livestock Science, Wageningen, The Netherlands

*These authors contributed equally to this study.

Corresponding authors: C.R. Ge / J.J. Jia

E-mail: gcrzal@126.com / junjingli2009@hotmail.com

Genet. Mol. Res. 15 (4): gmr.15048815

Received May 17, 2016

Accepted July 12, 2016

Published October 5, 2016

DOI http://dx.doi.org/10.4238/gmr.15048815

Copyright (C) 2016 The Authors. This is an open-access article distributed under the terms of the Creative Commons Attribution ShareAlike (CC BY-SA) 4.0 License.

\begin{abstract}
Chicken skeletal muscle satellite cells are located between the basement membrane and the sarcolemma of mature muscle fibers. Avian broilers have been genetically selected based on their high growth velocity and large muscle mass. The Wuding chicken is a famous local chicken in Yunnan Province that undergoes non-selection breeding and is slow growing. In this study, we aimed to explore differences in the proliferation and differentiation properties of satellite cells isolated from the two chicken breeds. Using immunofluorescence,
\end{abstract}


hematoxylin-eosin staining and real-time polymerase chain reaction analysis, we analyzed the in vitro characteristics of proliferating and differentiating satellite cells isolated from the two chicken breeds. The growth curve of satellite cells was S-shaped, and cells from Wuding chickens entered the logarithmic phase and plateau phase 1 day later than those from Avian chicken. The results also showed that the two skeletal muscle satellite cell lines were positive for Pax7, MyoD and $I G F-1$. The expression of $\operatorname{Pax} 7$ followed a downward trend, whereas that of $M y o D$ and $I G F-1$ first increased and subsequently decreased in cells isolated from the two chickens. These data indicated that the skeletal muscle satellite cells of Avian chicken grow and differentiate faster than did those of Wuding chickens. We suggest that the methods of breeding selection applied to these breeds regulate the characteristics of skeletal muscle satellite cells to influence muscle growth.

Key words: Avian chicken; Wuding chicken; Skeletal muscle satellite cells; Cell growth curves; Genetic resources

\section{INTRODUCTION}

Skeletal muscle satellite cells, also called muscle stem cells, are located between the basal lamina and plasmalemma of myofiber and play an important role in postnatal muscle growth, repair, and maintenance (Zammit et al., 2006a,b; Sacco et al., 2008). These cells were first isolated from frog muscle and were later identified in adult avian and mammalian muscle (Mauro, 1961). In recent decades, research on the function and mechanism of action of satellite cells in muscle development and regeneration has increased markedly. Satellite cells are mitotically quiescent, indifferent mononuclear small spherical cells distributed in normal mature skeletal muscle, but are activated to proliferate and differentiate as part of myonuclear turnover or for the formation of other cell types, such as osteocytes, adipocytes, and neurocytes. Therefore, skeletal muscle satellite cells are considered to be the major source of skeletal muscle fiber regeneration following skeletal muscle growth and injury (Schultz and McCormick, 1994). Pax7, Myf5, MyoD, MyoG, and MRF4 are myocellular proteins, which can be used as markers to determine the proliferation and differentiation status of satellite cells. Pax7 is only expressed in quiescent satellite cells, and activated satellite cells express Myf5, MyoD, Myogenin, and MRF4 (Yablonka-Reuveni and Rivera, 1994; Zammit, 2008).

Theoretically, the number of muscle fibers should not vary following embryonic development, with an increase in muscle mass being due to the hypertrophy of skeletal muscle fibers after birth, which is mainly due to the proliferation of muscle satellite cells and their fusion with muscle fiber. Avian broilers (selected chicken for meat production) and Wuding chickens (non-selected chicken) are ideal models to explore the regulatory mechanisms determining the rate of myogenesis and muscle fiber size. During the past few decades, Avian chicken, as broilers, have been genetically selected due to their high growth velocity and large muscle mass; however, the Wuding chicken is a famous local chicken in Yunnan Province with non-selection breeding and slow growth. There are large differences in the skeletal muscle phenotype of the two breeds, and the growth rate of Avian broiler muscle is higher than that of Wuding chickens.

Genetics and Molecular Research 15 (4): gmr.15048815 
In this study, we used a blood cell counting chamber to analyze the proliferation characteristics of muscle satellite cells isolated from 4-week-old chickens, and determined the expression of related genes during the differentiation phase of satellite cells isolated from both chicken lines by RT-PCR. The objective of this research was to investigate the molecular mechanisms underlying the differentiation and proliferation of skeletal muscle stem cells (satellite cells) in Avian broiler chicken and in Wuding chicken used in selection breeding.

\section{MATERIAL AND METHODS}

\section{Ethics statement}

All of the experiments complied with the requirements of the Directory Proposals on the Ethical Treatment of Experimental Animals in China.

\section{Animals}

Avian broiler chickens were purchased from Kunming Zhengda Group and Wuding chickens were obtained from Yunan Agriculture University. All chickens were grown under the same conditions and fed a diet consistent with the Chinese chicken Feeding Standard recommendations and the formulation of NRC 1994. All the experiments complied with the requirements of Yunan Agriculture University's Animal Care. Twenty randomly selected Yunnan Wuding chickens and 20 Avian broiler individuals with 4 weeks old were sacrificed.

\section{Cell culture}

Muscle samples were soaked for $15 \mathrm{~min}$ in $75 \%$ ethanol to sterilize external surfaces, placed in sterilized gauze to isolate skeletal muscles, and cut into $\sim 1-\mathrm{mm}^{3}$ pieces using ophthalmic scissors. These pieces were disaggregated by digestion with $0.1 \%$ collagenase I for $20 \mathrm{~min}$ and $0.25 \%$ trypsin for $30 \mathrm{~min}$ at $37^{\circ} \mathrm{C}$. Next, Dulbecco modified Eagle medium (DMEM) containing 10\% horse serum (HS), $5 \%$ chicken serum (CS), and 1\% amphotericin B (Biochrom, Germany) was added to terminate the reaction. The cell suspensions were filtered through 70- and 40-mm nylon cell strainers, and then centrifuged at $1000 \mathrm{rpm}$ for $5 \mathrm{~min}$ with the supernatant discarded. Cells were resuspended in complete medium (DMEM/F12, 10\% HS, $5 \%$ CS, $1 \%$ amphotericin B) and seeded in cell culture bottles. Cells were cultured in a 5\% $\mathrm{CO}_{2}$ incubator at $37^{\circ} \mathrm{C}$ for $2 \mathrm{~h}$. The cell suspensions were then transferred to a new cell culture bottle, and culture was continued with $5 \% \mathrm{CO}_{2}$ at $37^{\circ} \mathrm{C}$ (Qu et al., 1998).

When the cells reached $80-90 \%$ confluence, $0.25 \%$ trypsin containing $0.02 \%$ EDTA was added to digest cells, which were then subcultured at a ratio of 1:2.

The cells were subcultured to passage three until they reached $80-90 \%$ confluence, and were then digested and centrifuged and the supernatant was discarded. Then, $1.5 \mathrm{~mL}$ freezing medium $(20 \% \mathrm{HS}+10 \% \mathrm{CS}+10 \%$ dimethyl sulfoxide $+60 \% \mathrm{DMEM} / \mathrm{F} 12)$ was added. The suspension was dispensed into freezing tubes, and incubated at $4^{\circ} \mathrm{C}$ for $30 \mathrm{~min},-20^{\circ} \mathrm{C}$ for $1 \mathrm{~h}$, and $-80^{\circ} \mathrm{C}$ overnight, before being transferred into a liquid nitrogen tank for long-term preservation. To recover cells, the freezing tubes were removed from the liquid nitrogen and placed rapidly into a $37^{\circ} \mathrm{C}$ water bath until the contents were $90 \%$ melted. Cells were then centrifuged at $1000 \mathrm{rpm}$ for $5 \mathrm{~min}$ with the supernatant discarded. Complete medium was added and the cells were cultured in a $37^{\circ} \mathrm{C}, 5 \% \mathrm{CO}_{2}$ incubator.

Genetics and Molecular Research 15 (4): gmr.15048815 


\section{Identification of skeletal muscle satellite cells}

\section{Preliminary identification by RT-PCR}

Cells in passage three were collected and total RNA was extracted using TRIzol (Invitrogen, USA). Total RNA was reverse transcribed to cDNA using a SYBR-Green kit (iQTM SYBR-Green ${ }^{\circledR}$ Supermix, Dalian TaKaRa Biotechnology Co. Ltd.). The expression of Pax7 and MyoD, which encode muscle-specific proteins, was determined by RT-PCR to identify and evaluate the purity of satellite cells. Information on the primer pairs used is listed in Table 1. PCR was performed in a $25-\mu \mathrm{L}$ mixture containing $12.5 \mu \mathrm{L}$ IQ SYBR Green Supermix, $9.5 \mu \mathrm{L} \mathrm{dH}_{2} \mathrm{O}, 1 \mu \mathrm{L}$ forward and reverse primers, and $1 \mu \mathrm{L}$ template cDNA. The cycling conditions consisted of an initial $2 \mathrm{~min}$ at $94^{\circ} \mathrm{C}$ for one cycle followed by 40 cycles of $30 \mathrm{~s}$ at $94^{\circ} \mathrm{C}$ for denaturing, $30 \mathrm{~s}$ at $50-60^{\circ} \mathrm{C}$ for annealing, and $30 \mathrm{~s}$ at $72^{\circ} \mathrm{C}$ for extension. PCR products were detected by $2.5 \%$ agarose gel electrophoresis. Levels of gene expression were determined by expression relative to $18 \mathrm{~S}$.

\begin{tabular}{|c|c|c|c|c|}
\hline Gene & Sequence & $\operatorname{Tm}\left({ }^{\circ} \mathrm{C}\right)$ & Length (bp) & Cycles \\
\hline \multirow{2}{*}{ MyoD } & F:gatttccacagacaactccaca & \multirow{2}{*}{61.7} & \multirow{2}{*}{188} & \multirow{2}{*}{40} \\
\hline & R:cttggtagattggattgctgct & & & \\
\hline \multirow[t]{2}{*}{ Pax7 } & F:gctgacttctccatctctcctc & \multirow[t]{2}{*}{61.7} & \multirow[t]{2}{*}{155} & \multirow[t]{2}{*}{40} \\
\hline & R:ctgtaactggtggtgctgtagg & & & \\
\hline \multirow[t]{2}{*}{ IGF-1 } & F:agacgaggettctacttca & \multirow[t]{2}{*}{54} & \multirow[t]{2}{*}{153} & \multirow[t]{2}{*}{40} \\
\hline & R:gcagatttaggtggcttt & & & \\
\hline \multirow[t]{2}{*}{$18 \mathrm{~S}$} & F:cgcgtgcatttatcagacca & \multirow[t]{2}{*}{58} & \multirow[t]{2}{*}{148} & \multirow[t]{2}{*}{40} \\
\hline & R:acccgtggtcaccatggta & & & \\
\hline
\end{tabular}

\section{Immunofluorescence}

Cells in passage two were collected and seeded on 6-well plates at a density of $1 \times 10^{5}$ cells $/ \mathrm{mL}$. Pax 7 Immunofluorescence was detected during proliferation at 2 and 4 days. The cells were washed with phosphate buffered saline (PBS), fixed with 4\% paraformaldehyde for $10 \mathrm{~min}$ at room temperature, and washed three times with PBS (3 min each). Then, the samples were incubated for 20 min with $0.5 \%$ Triton X-100

for permeabilization and washed three times with PBS ( 3 min each). To prevent nonspecific binding of antibodies, the samples were blocked in $5 \%$ bovine serum albumin for $20 \mathrm{~min}$ at room temperature. After incubation overnight at $4^{\circ} \mathrm{C}$ with anti-pax7 (1:50, Santa Cruz Technology), the primary antibody was removed and the cells were washed three times with PBS (3 min each). Fluorescein isothiocyanate goat anti-mouse IgG secondary antibody (1:100, Zhongshan Golden Bridge, Beijing) was added and samples were incubated for $1 \mathrm{~h}$ at room temperature in a darkroom. The secondary antibody solution was decanted and samples were washed three times with PBS (5 min each) in the dark. Finally, the cells were coated with anti-fluorescence attenuator for microscopic analysis.

\section{Growth curves for Wuding chicken and Avian broiler cells}

Passage three cells were digested with $0.25 \%$ trypsin, and seeded on 24 -well plates at a density of $2.25 \times 10^{4}$ cells $/ \mathrm{mL}$. Every $24 \mathrm{~h}$ two wells were counted with a blood-cell counting 
chamber until the twelfth day, to ensure accuracy, each well was counted three times and the average number was taken. If cells overlapped, the original cell suspension was diluted and the cells recounted. Finally, time was taken as the abscissa and cell density as the vertical to generate the cell growth curve.

\section{Differentiation of skeletal muscle satellite cells}

Passage three cells grew to $70-80 \%$ confluence in culture, were washed three times with PBS, and then induced to differentiate into muscle cells by culturing in DMEM with $\%$ HS and $1 \%$ antibiotic for 8 days. The induction medium was changed every day (Katagiri et al., 1994). We collected induced cells at $0,1,3,5$, and 7 days and RNA was extracted with TRIzol. Total RNA was reverse transcribed for use in RT-PCR. Information on specific primer pairs is listed in Table 1.

\section{Statistical analysis}

The primers were designed by Primer 5 and the results are reported as means \pm standard deviation. The treatment effect was assessed using non-parametric Kruskal-Wallis analysis of variance (ANOVA; SPSS 19.0, StatSoft). When the ANOVA revealed a significant effect, a Mann-Whitney test was performed. The cycle threshold (CT) values for each treatment group were calculated as the $\Delta \mathrm{CT}=\mathrm{CT}$ (target gene) - CT (18S). All the experiments were performed at least twice. Within an experiment, results for each time point were obtained from three replicates.

\section{RESULTS}

\section{Morphology of skeletal muscle satellite cells}

Under an inverted microscope, primary chicken satellite cells were found to be round with strong refraction before adhering (Figure 1). After $24 \mathrm{~h}$ of culture, the cells began to adhere and were spindle shaped or fusoid (Figure 1). Their proliferative capacity increased over 48 $\mathrm{h}$ of culture and the cells were arranged regularly in parallel (Figure 1). In this experiment, the adherence capability of skeletal muscle satellite cells from Avian chicken was found to be stronger than that of cells from Wuding chicken. The proliferation rate of cells from Avian chicken is faster than that of cells from Wuding chicken.

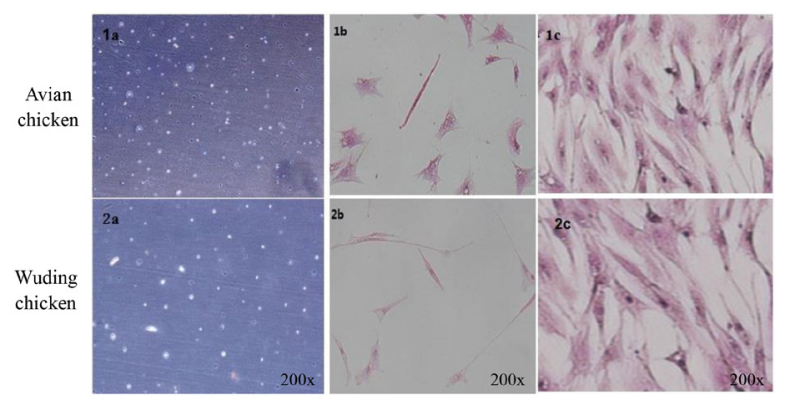

Figure 1. Morphology of cultured skeletal muscle satellite cells. 1a. 2a. Satellite cells were round and strong refraction. 1b. 2b. Cells were stained by hematoxylin eosin (H\&E), adherent cells were spindle-shaped or fusoid. 1c. 2c. With increase in cell density, cells were arranged in parallel, as shown by H\&E staining. 


\section{Identification of skeletal muscle satellite cells}

\section{Preliminary identification of RT-PCR}

In this study, we analyzed the mRNA expression of $\operatorname{Pax} 7$ and $M y o D$ genes, which are specific markers of satellite cells, in skeletal muscle satellite cells by RT-PCR. All skeletal muscle satellite cells isolated from the two chicken lines were positive for Pax7 and MyoD (Figure 2A-B). This confirms that the isolated cells are pure skeletal muscle satellite cells; these provided material for the further study of muscle satellite cell characteristics.

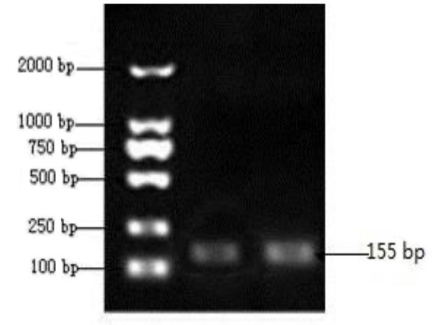

Avian Wuding

Pax7-A

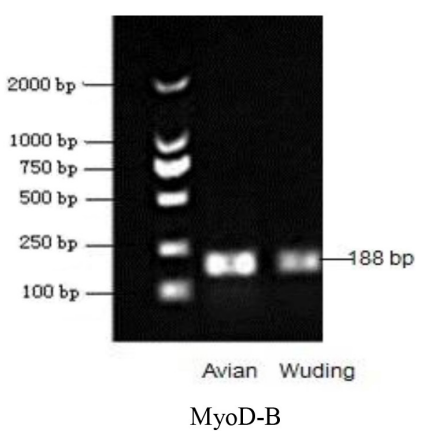

MyoD-B

Figure 2. RT-PCR analysis of skeletal muscle satellite cells. A. Samples from Avian and Wuding chickens were positive for Pax7. B. Avian and Wuding chickens were positive for MyoD.

\section{Immunofluorescence}

Pax7 is a specific marker of skeletal muscle satellite cells. In this experiment, Pax7 was found to be distributed in the nucleus, and was expressed in samples from Wuding and Avian chicken. Over time, an increasing number of satellite cells were positive for Pax7 (Figure 3A-D). This confirmed that the cultured cells were satellite cells.
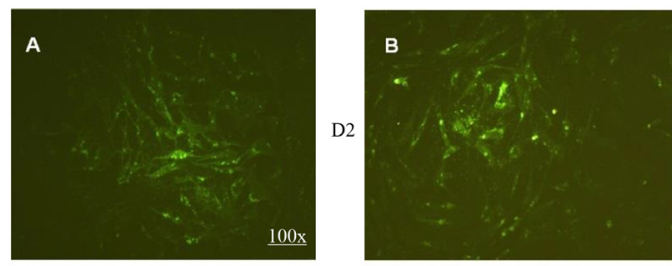

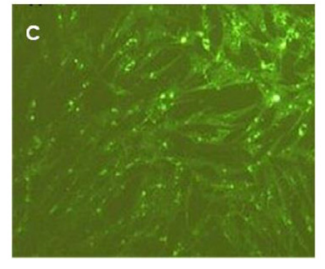

Wuding chicken

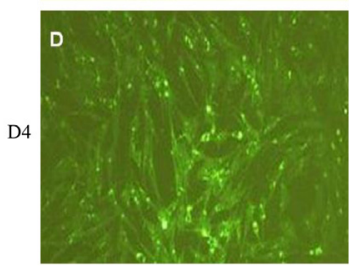

Avian chicken

Figure 3. Immunofluorescence detection of satellite cells. A.-C. Immunofluorescence analysis of Pax7 in myogenic cells from Wuding chicken following 2 and 4 days of proliferation. B.-D. Immunofluorescence analysis of Pax 7 in myogenic cells from Avian chicken following 2 and 4 days of proliferation. 


\section{Growth characteristics of skeletal muscle satellite cells}

Passage-three cells were used to generate growth curves of the two chicken lines (Figure 4). There were differences in the development of skeletal muscle satellite cells between Avian chicken and Wuding chicken, and the standard curve was almost S-shaped. Avian chicken cells entered the logarithmic phase after 2-days proliferation and myoblasts proliferated rapidly from days 2 to 8 . The rate of proliferation then slowed after 8 days and cells entered the plateau phase. However, cells from Wuding chickens entered these phases one-day later than those from Avian chickens, and the number of satellite cells was lower than in Avian chicken at day 7 and $8(\mathrm{P}<0.05)$.

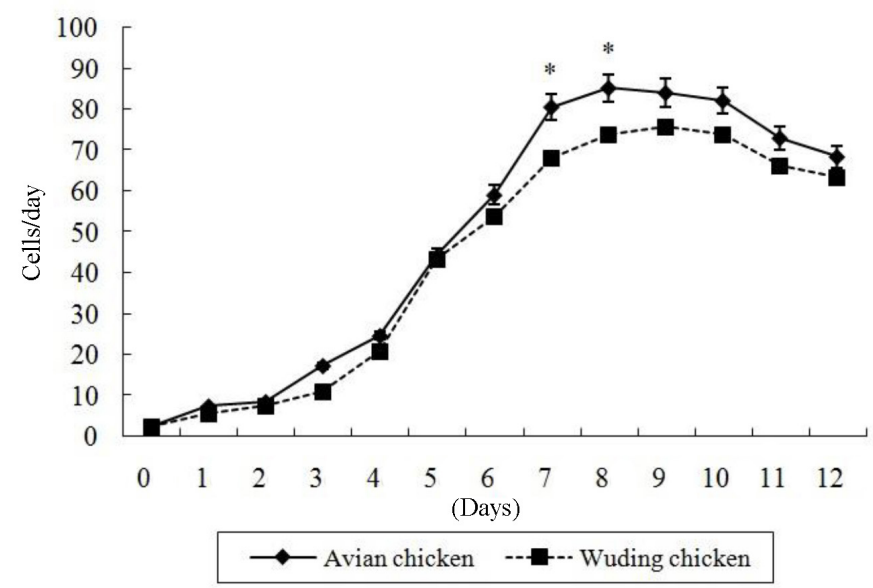

Figure 4. Growth curve of skeletal muscle satellite cells from Avian chicken and Wuding chicken. *Significantly $(\mathrm{P}<0.05)$ different means. Significant differences were determined by the Mann-Whitney rank test. Results were obtained from three replicates.

\section{Differentiation of skeletal muscle satellite cells}

Cells proliferated slowly when cultured in the induction medium, and anastomosis began to develop between cells. The ability of cells from Avian chicken to fuse into myotubes increased over time as compared with that those from Wuding chicken. The myotubes were observed by day 3 (Figure 5 1a-1b), and after 5 days, many mononucleate myoblasts were fused with centrally located nuclei, forming long bamboo-shaped primary myoblasts (myotubule) with a regular parallel arrangement (Figure $52 \mathrm{a}-2 \mathrm{~b}$ ).

\section{RT-PCR}

In this experiment, the expression of $\operatorname{Pax} 7, M y o D$, and $I G F-1$ in skeletal muscle satellite cells during differentiation was assessed by RT-PCR. The results showed that the skeletal muscle satellite cells from the two chicken lines were positive for Pax7, MyoD, and $I G F-1$ (Figure 6). The expression of $18 \mathrm{~S}$ was used as an internal control. Over time, the expression of $\operatorname{Pax} 7$ began to decrease, and the expression of $M y o D$ and $I G F-1$ first increased and then decreased in samples from the two chickens. 


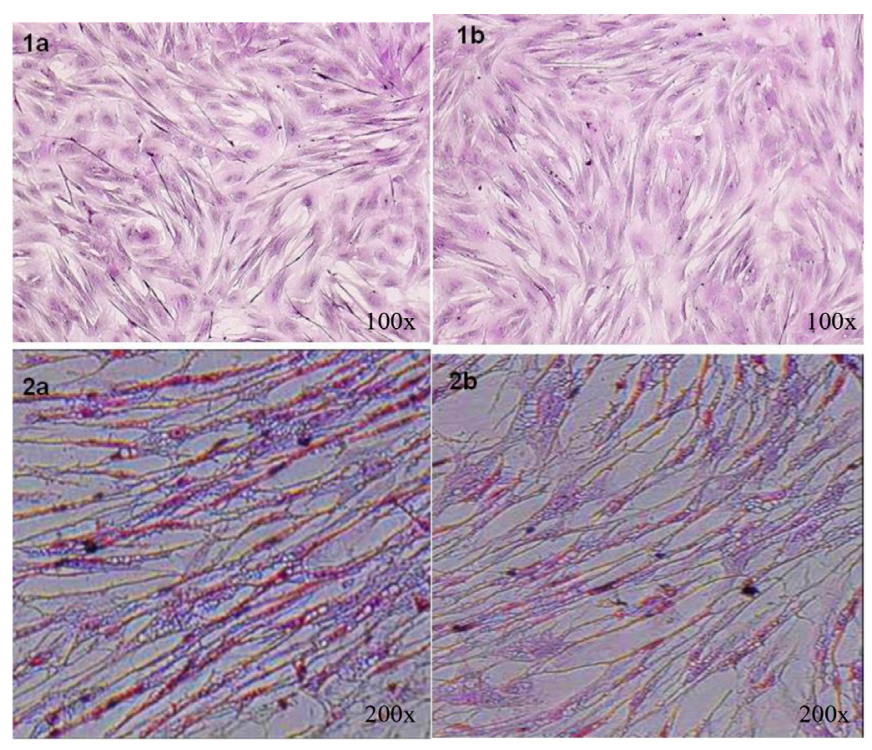

Avian chicken

Wuding chicken

Figure 5. Skeletal muscle satellite cells differentiate into myogenic cells. 1a. 1b. Myotubes were formed after 3 days of differentiation and observed by H\&E staining in samples from Avian chicken and Wuding chicken, respectively. 2a. 2b. Skeletal muscle satellite cells initiated terminal differentiation to form multinucleated myotubes on day 5 .

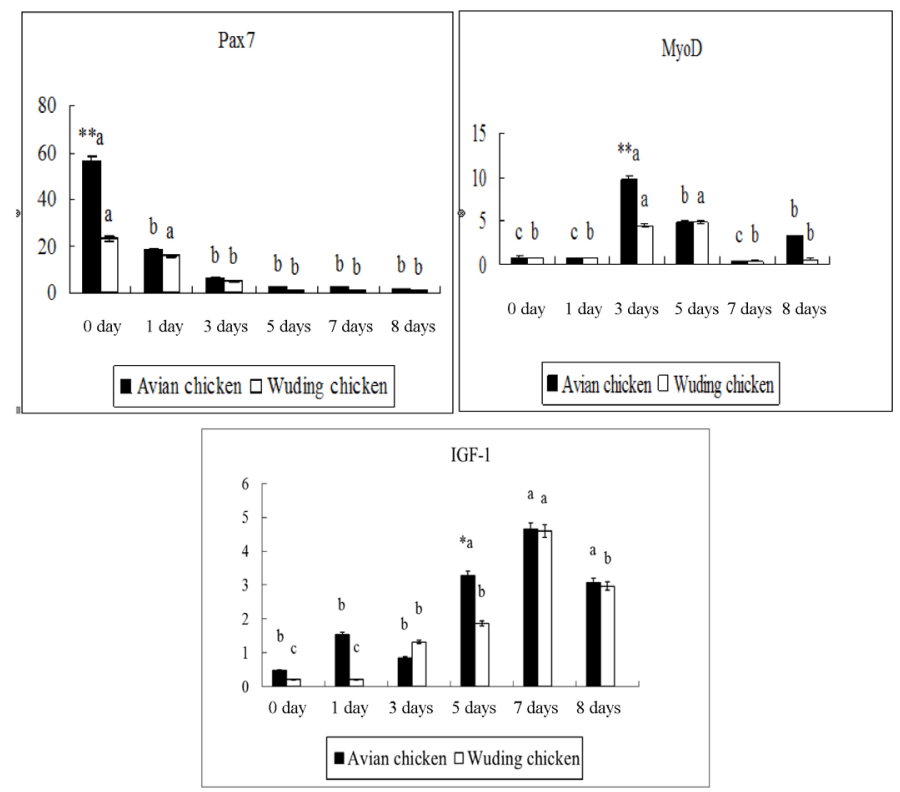

Figure 6. Differentiation of myogenic cells at days $0,1,3,5,7$, and 8 . The expression of Pax 7 , MyoD, and IGF-1 in skeletal muscle satellite cells was determined by RT-PCR. **Differences among different chickens at the same time are significant $(\mathrm{P}<0.01)$. Significant difference $(\mathrm{P}<0.05)$. Different letters indicate significantly different means $(\mathrm{P}<0.05)$.

Genetics and Molecular Research 15 (4): gmr.15048815 
The expression of $\operatorname{Pax} 7$ in skeletal muscle satellite cells from Avian chicken at day 0 was significantly higher than at any other time assessed $(\mathrm{P}<0.01)$. The expression of $\operatorname{Pax} 7$ in cells from Wuding chicken on day 0 and day 1 was significantly higher than at any other time $(\mathrm{P}<0.01)$. Over the course of the experiment, gene expression in cells from Avian chicken was higher than in those from Wuding chicken, and maximum expression in samples from both chicken was maximal at day 0 .

Expression of the $M y o D$ gene in skeletal muscle satellite cells from Avian chicken and Wuding chicken on day 3 was significantly higher than on any other day $(\mathrm{P}<0.01)$. The expression of this gene in Wuding chicken was significantly lower than in Avian chicken ( $\mathrm{P}$ $<0.01$ ), compared with the other days. Overall, expression of this gene was higher in Avian chicken than in Wuding chicken.

Expression of the $I G F-1$ gene in skeletal muscle satellite cells from Avian chicken at days 5,7 , and 8 was significantly higher than on other days $(\mathrm{P}<0.01)$. Expression of this gene in cells from Wuding chicken on days 7 and 8 was significantly higher than on any other days $(\mathrm{P}<0.01)$. The maximum expression in the two chicken lines occurred on day 7; expression of $I G F-1$ in cells from Avian chicken was higher than that in cells from Wuding chicken on all days, with the exception of day 3 .

\section{DISCUSSION}

Satellite cells are a type of adult muscle stem cells and are located between the basal lamina and the basement membrane of mature myofibers. They play a key role in the growth of skeletal muscle and in the regulation of muscle growth and development in the post-hatch stage, which is the first stage of muscle growth in adults.

In the present study, the method used to isolate skeletal muscle satellite cells from Wuding and Avian chickens was similar to that used in studies on other animals. We adopted a modified two-step method using collagenase and trypsin to isolate skeletal muscle satellite cells. These cells were then purified using the differential time attachment method, which utilizes the differential adhesive abilities of fibroblasts and satellite cells (Lee et al., 2000). Basal keratinocytes were isolated from skin based on their differential adhesive abilities (Häkkinen et al., 2001; Spichkina et al., 2008).

Pax7 (Seale et al., 2000), M-Cadherin, Desmin, c-Met, MNF, MyoD (Musarò and Barberi, 2010; Wu et al., 2012), MyoG, and $M y f 5$ are specific markers of skeletal muscle satellite cells. Pax7, M-Cadherin, and c-Met can be used to identify quiescent satellite cells and the molecular markers $M y f 5, M y o D$, and Desmin are used to identify proliferating satellite cells. In the present study, Pax7 and MyoD were used to identify skeletal muscle satellite cells by RT-PCR and immunofluorescence. Cultured cells were shown to be pure skeletal muscle satellite cells and were positive for Pax7 and MyoD.

Previous studies demonstrated that the proliferating ability of satellite cells varies in chicken. In our study, the growth curves for skeletal muscle cells from Wuding chicken and Avian chicken were "S" type, and included incubation, growth, platform, and apoptosis stages. Compared with Avian chicken, skeletal muscle satellite cells from Wuding chicken growing in the corresponding logarithmic and platform phase was possibly delayed and their growth rate was sluggish. For the differentiation of satellite cells, different breeds adopt different inducing medium. In a previous study, induction medium containing DMEM with 5\% HS was added to differentiate Beijing fatty chicken skeletal muscle cells (Bai et al., 2012). In another study,

Genetics and Molecular Research 15 (4): gmr.15048815 
muscle cells were cultured in DMEM containing 5\% FBS and $1 \mu \mathrm{M}$ cytosine arabinoside for pig satellite cells (Perruchot et al., 2012). In the present study, we used induction medium containing DMEM/F12 and 2\% HS, and multinucleated myotubes were observed clearly on day 5. This is important for skeletal muscle hypertrophy and fiber-type transformation, and ultimately affects meat quality. In addition, the Avian chicken cells formed stronger myotubes than Wuding chicken cells. These data indicate that the skeletal muscle of Avian chicken grows faster than that of Wuding chicken and this is related to the characteristics of the satellite cells.

The myogenic potential of skeletal muscle satellite cells depends on the expression of Pax3/7 and on myogenic regulatory factors (including MyoD, Myf5, and MRFs). IGFs also play a key role in the growth of satellite cells. Changes in gene expression and in the activity of IGF have been studied during cell culture progression (Castillo et al., 2002, 2004, 2006; Codina et al., 2008). Expression of the $I G F-1$ gene was reported to be upregulated, when the satellite cells were activated by weight-bearing exercise or trauma (Adams and McCue, 1998). Nevertheless, cell differentiation has been reported to start at the peak of the proliferation curve (Fauconneau and Paboeuf, 2000; Bower and Johnston, 2010). Therefore, we analyzed the expression of $P a x 3, M y o D$, and IGF-1 in differentiating cells. The results showed that the Pax3 gene was expressed at the highest levels in cells from the two chickens on day 0. For $M y o D$, the highest gene expression as observed on day 3 . These results are consistent with those of previous reports (Chen, et al., 2010). When the muscle satellite cells are stimulated, Pax7 is expressed, leading to the activation of quiescent satellite cells. Skeletal muscle progenitor cells were formed following the proliferation of satellite cells, and Pax3, Myf5, and $M y o D$ were upregulated while $\operatorname{Pax} 7$ was expressed at lower levels. Overall, the expression of Pax , MyoD, and IGF-1 in cells from Wuding chicken was lower than that in cells from Avian chicken. This is reflected in higher growth rate of Avian chicken muscle compared with Wuding chicken muscle.

In conclusion, we established a technology platform involving the isolation and in vitro induction of skeletal muscle satellite cell differentiation. The characteristics of Wuding and Avian chicken skeletal muscle satellite cells were compared and analyzed in terms of their proliferation and differentiation abilities, and the skeletal muscle cells from Avian chicken were found to grow and differentiate faster than those from Wuding chicken. Furthermore, these cells differ in their sensitivity to related genes. These results provide references for the further study of skeletal muscle growth and development in selection and non-selection chicken. We have suggested a new method to preserve the valuable genetic resources of Wuding chicken. Wuding chicken is part of the abundant poultry genetic resources in Yunnan, further studies should expand the number of samples to include large numbers of chicken samples of different genetic backgrounds and related screening candidate genes to further investigate the function of skeletal muscle satellite cells in muscle growth and development of native chickens.

\section{Conflicts of interest}

The authors declare no conflict of interest.

\section{ACKNOWLEDGMENTS}

Research supported by the National Natural Science Foundation Research Projects (\#31260532, \#31560618 and \#31572359), the Yunnan Science and Technology Key Project 
(\#2016FA046), and National Science and Technology Program in 13th Five-Year Plan (\#2015BAD03B03-4).

\section{REFERENCES}

Adams GR and McCue SA (1998). Localized infusion of IGF-I results in skeletal muscle hypertrophy in rats. J. Appl. Physiol. 84: 1716-1722.

Bai C, Hou L, Li F, He X, et al. (2012). Isolation and biological characteristics of beijing Fatty chicken skeletal muscle satellite cells. Cell Commun. Adhes. 19: 69-77. http://dx.doi.org/10.3109/15419061.2012.743998

Bower NI and Johnston IA (2010). Paralogs of Atlantic salmon myoblast determination factor genes are distinctly regulated in proliferating and differentiating myogenic cells. Am. J. Physiol. Regul. Integr. Comp. Physiol. 298: R1615-R1626. http://dx.doi.org/10.1152/ajpregu.00114.2010

Castillo J, Le Bail PY, Paboeuf G, Navarro I, et al. (2002). IGF-I binding in primary culture of muscle cells of rainbow trout: changes during in vitro development. Am. J. Physiol. Regul. Integr. Comp. Physiol. 283: R647-R652. http:// dx.doi.org/10.1152/ajpregu.00121.2002

Castillo J, Codina M, Martínez ML, Navarro I, et al. (2004). Metabolic and mitogenic effects of IGF-I and insulin on muscle cells of rainbow trout. Am. J. Physiol. Regul. Integr. Comp. Physiol. 286: R935-R941. http://dx.doi. org/10.1152/ajpregu.00459.2003

Castillo J, Ammendrup-Johnsen I, Codina M, Navarro I, et al. (2006). IGF-I and insulin receptor signal transduction in trout muscle cells. Am. J. Physiol. Regul. Integr. Comp. Physiol. 290: R1683-R1690. http://dx.doi.org/10.1152/ ajpregu.00294.2005

Chen JF, Tao Y, Li J, Deng Z, et al. (2010). microRNA-1 and microRNA-206 regulate skeletal muscle satellite cell proliferation and differentiation by repressing Pax7. J. Cell Biol. 190: 867-879. http://dx.doi.org/10.1083/ jcb. 200911036

Codina M, García de la serrana D, Sánchez-Gurmaches J, Montserrat N, et al. (2008). Metabolic and mitogenic effects of IGF-II in rainbow trout (Oncorhynchus mykiss) myocytes in culture and the role of IGF-II in the PI3K/Akt and MAPK signalling pathways. Gen. Comp. Endocrinol. 157: 116-124. http://dx.doi.org/10.1016/j.ygcen.2008.04.009

Fauconneau B and Paboeuf G (2000). Effect of fasting and refeeding on in vitro muscle cell proliferation in rainbow trout (Oncorhynchus mykiss). Cell Tissue Res. 301: 459-463. http://dx.doi.org/10.1007/s004419900168

Häkkinen L, Koivisto L and Larjava H (2001). An improved method for culture of epidermal keratinocytes from newborn mouse skin. Methods Cell Sci. 23: 189-196. http://dx.doi.org/10.1023/A:1016385109922

Katagiri T, Yamaguchi A, Komaki M, Abe E, et al. (1994). Bone morphogenetic protein-2 converts the differentiation pathway of $\mathrm{C} 2 \mathrm{C} 12$ myoblasts into the osteoblast lineage. J. Cell Biol. 127: 1755-1766. http://dx.doi.org/10.1083/ jcb.127.6.1755

Lee JY, Qu-Petersen Z, Cao B, Kimura S, et al. (2000). Clonal isolation of muscle-derived cells capable of enhancing muscle regeneration and bone healing. J. Cell Biol. 150: 1085-1100. http://dx.doi.org/10.1083/jcb.150.5.1085

Mauro A (1961). Satellite cell of skeletal muscle fibers. J. Biophys. Biochem. Cytol. 9: 493-495. http://dx.doi.org/10.1083/ jcb.9.2.493

Musarò A and Barberi L (2010). Isolation and culture of mouse satellite cells. Methods Mol. Biol. 633: 101-111. http:// dx.doi.org/10.1007/978-1-59745-019-5 8

Perruchot MH, Ecolan P, Sorensen IL, Oksbjerg N, et al. (2012). In vitro characterization of proliferation and differentiation of pig satellite cells. Differentiation 84: 322-329. http://dx.doi.org/10.1016/j.diff.2012.08.001

Qu Z, Balkir L, van Deutekom JC, Robbins PD, et al. (1998). Development of approaches to improve cell survival in myoblast transfer therapy. J. Cell Biol. 142: 1257-1267. http://dx.doi.org/10.1083/jcb.142.5.1257

Sacco A, Doyonnas R, Kraft P, Vitorovic S, et al. (2008). Self-renewal and expansion of single transplanted muscle stem cells. Nature 456: 502-506. http://dx.doi.org/10.1038/nature07384

Seale P, Sabourin LA, Girgis-Gabardo A, Mansouri A, et al. (2000). Pax7 is required for the specification of myogenic satellite cells. Cell 102: 777-786. http://dx.doi.org/10.1016/S0092-8674(00)00066-0

Schultz E and McCormick KM (1994). Skeletal muscle satellite cells. Rev. Physiol. Biochem. Pharmacol. 123: 213-257. http://dx.doi.org/10.1007/BFb0030904

Spichkina OG, Pinaev GP and Petrov IuP (2008). Analysis of heterogeneity of human keratinocyte populations by their adhesion to substrate and the keratin 19 to actin ratio. Tsitologiia 50: 218-227.

Wu H, Ren Y, Li S, Wang W, et al. (2012). In vitro culture and induced differentiation of sheep skeletal muscle satellite cells. Cell Biol. Int. 36: 579-587. http://dx.doi.org/10.1042/CBI20110487

Genetics and Molecular Research 15 (4): gmr.15048815 
Yablonka-Reuveni Z and Rivera AJ (1994). Temporal expression of regulatory and structural muscle proteins during myogenesis of satellite cells on isolated adult rat fibers. Dev. Biol. 164: 588-603. http://dx.doi.org/10.1006/ dbio.1994.1226

Zammit PS (2008). All muscle satellite cells are equal, but are some more equal than others? J. Cell Sci. 121: 2975-2982. http://dx.doi.org/10.1242/jcs.019661

Zammit PS, Partridge TA and Yablonka-Reuveni Z (2006a). The skeletal muscle satellite cell: the stem cell that came in from the cold. J. Histochem. Cytochem. 54: 1177-1191. http://dx.doi.org/10.1369/jhc.6R6995.2006

Zammit PS, Relaix F, Nagata Y, Ruiz AP, et al. (2006b). Pax7 and myogenic progression in skeletal muscle satellite cells. J. Cell Sci. 119: 1824-1832. http://dx.doi.org/10.1242/jcs.02908

Genetics and Molecular Research 15 (4): gmr.15048815 